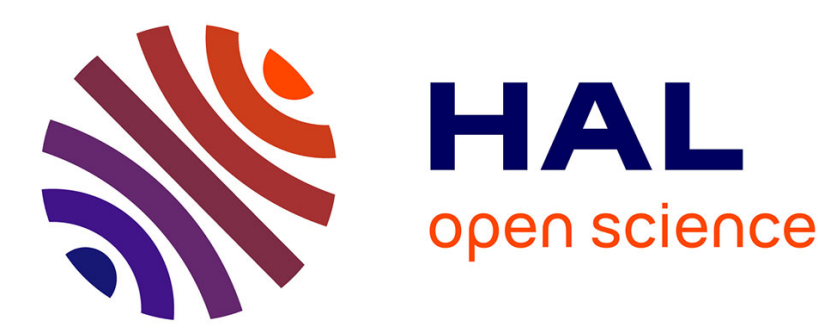

\title{
The legacy of Professor Jacques Angelier Introduction
}

Agust Gudmundsson, Françoise Bergerat

\section{To cite this version:}

Agust Gudmundsson, Françoise Bergerat. The legacy of Professor Jacques Angelier Introduction.

Tectonophysics, 2012, 581, pp.1-5. 10.1016/j.tecto.2012.10.014 . hal-00832198

\section{HAL Id: hal-00832198 \\ https://hal.science/hal-00832198}

Submitted on 14 Jun 2013

HAL is a multi-disciplinary open access archive for the deposit and dissemination of scientific research documents, whether they are published or not. The documents may come from teaching and research institutions in France or abroad, or from public or private research centers.
L'archive ouverte pluridisciplinaire HAL, est destinée au dépôt et à la diffusion de documents scientifiques de niveau recherche, publiés ou non, émanant des établissements d'enseignement et de recherche français ou étrangers, des laboratoires publics ou privés. 
Introduction: The Legacy of Professor Jacques Angelier

This volume on 'Crustal Stresses, Fractures, and Fault Zones' is dedicated to the legacy of Professor Jacques Angelier who was one of world's leading structural geologists. Here we present a brief overview of his academic career, scientific work, and legacy.

Education, appointments, and awards

Jacques François Olivier Angelier (Fig. 1), to give his full name, was born 2 March 1947 in Ales in France. He passed away on 31 January 2010. Jacques was a student at 'Ecole Normale Supérieure' of Saint-Cloud from 1966 to 1970. He obtained his PhD in 1970 and his DSc in 1979. From 1970-71 Jacques was an assistant lecturer at the University of Pierre and Marie Curie in Paris (Paris VI), and from 1971-76 an assistant lecturer at the University of Orléans.

Following his stay in Orléans, Jacques returned to University Pierre and Marie Curie in Paris in 1976 as an assistant professor and, from 1981, as a full professor. Jacques worked as a professor in Paris until 2003, when he took up the post of a professor at the Oceanological Observatory of Villefranche-sur-Mer (close to the city of Nice), also a part of University of Paris VI. Jacques was married to Nicole Angelier (née Delobel) and they had two children, a son Frédéric and a daughter Ariane.

Jacques Angelier was a member of various societies and academies in France and abroad. These include the Academia Europaea (The Academy of Europe), of which he was elected member in 1999, and the French Academy of Sciences, of which he was a corresponding member since 1997. He was also a member of The European Academy of Sciences (Académie Européenne des Sciences), which operates under the rules and regulations of the Kingdom of Belgium, from 2003, and a senior member of the 'Institut Universitaire de France' from 1997 to 2007.

Jacques received several awards for his outstanding scientific contributions. These include the Victor Raulin Prize of the Academy of Sciences (1991) and the Fourmarier Prize of the Royal Academy of Belgium (1995). In addition, he got the prize of the France-Taiwan Foundation of the Institute of France in 1999 and was also 'Chevalier des Palmes 
Académiques', an honour given to people of distinction who work under the Ministry of Education in France.

\section{Research and teaching}

The main research activities of Jacques Angelier were within the fields of structural geology and geodynamics, his focus being on brittle deformation (Fig. 2). He was a world leader in analysing crustal stresses, that is, in developing methods to understand the various stress fields to which the Earth's crust has been subject through time. The basic techniques are inversion of fault-slip data from fault sets in the field and focal mechanisms (fault-plane solutions) of numerous recorded earthquakes in a given area to calculate the state of stress.

Inversion of fault data is primarily used for palaeostresses, that is, to infer the state of stress that existed at the time of fault slip. This method relies much on measurements and correct interpretation of striae (slickensides) on fault planes in the field. Focal mechanisms are used to infer current stresses from seismogenic faulting (earthquakes) in active fault zones. Jacques also developed computer programs to calculate the stress tensors from these types of data. The 'Angelier method' in brittle-deformation studies is well known to geologists and geophysicists working on brittle tectonics and earthquakes worldwide, both the field approach and the theoretical approach, including the stress-tensor program 'Tector Software System', which he developed over many years and which is widely used.

Jacques Angelier also made regional and local brittle-tectonic studies in many countries and regions. These include North Africa, Greece, Turkey, Mexico, the United States, Japan, Korea, Russia, Ukraine, Iran, Canada, Greenland, Taiwan, and Iceland. Part of his research extended into the sea floor. He participated in campaigns in the Mediterranean Sea and the Pacific Ocean, and in dives on the Provence margin in France, and into the Hellenic Trench (of the Ionian Sea) and the Japan Trench.

Since the late 1980's, his research focused increasingly on active deformation (Fig. 3). This work enabled him to combine field studies of brittle deformation with the analysis of earthquakes, the focus being on seismotectonics and associated stress fields. The main areas of his seismotectonic studies were in Iceland and especially in Taiwan, a country he loved very much. These two countries, both at active plate boundaries, gave Jacques the 
opportunity to study earthquakes in widely different plate-tectonic settings: primarily a divergent plate boundary in the case of Iceland (Fig. 3), and primarily a convergent plate boundary in case of Taiwan (Fig. 4).

Jacques Angelier's research led him, throughout his career, to establish collaborations with many geological and geophysical institutes worldwide. In Iceland, these include the Iceland Meteorological Office (IMO) and the Iceland GeoSurvey (ISOR), both in Reykjavik. In Taiwan, the institutes with which Jacques collaborated include the Academia Sinica and the in Geological Survey, both in Taipei, as well as universities such as Taïda and the Central University of Chung Li. In 2007, Jacques was a leading person in initiating the TaiwanFrance International Laboratory 'ADEPT' (Active Deformation and Environment Program for Taiwan) supported in France by the CNRS and in Taiwan by the National Science Council.

Jacques Angelier was an excellent teacher. He taught both at undergraduate and graduate levels numerous future teachers and academics. He had many graduate students, from different countries, such as Korea, Russia, and Taiwan, in addition to students from France. His main teaching focused on structural geology, tectonics, geophysics, and computer science. His great enthusiasm and ability as a teacher were an inspiration to many students who are currently employed in various positions worldwide. In addition to his teaching duties, Jacques was also for a while the Head of the Tectonics Laboratory at University Pierre and Marie Curie in Paris.

As a scientist, Jacques Angelier was outstandingly productive. He is an author on 285 papers in the Web of Science (ISI) database. He commonly published 5-10 papers, and sometimes as many as 12-14 papers, per year. Together his papers have got as many as 500 citations in a single year, with six papers exceeding a cumulative total of 200 citations each. These papers are on the Hellenic Trench, and the associated arc, and on the determination of the state of stress from fault-slip data sets. His 285 papers have received a total of more than 7300 citations, suggesting that Jacques Angelier may be the most highly cited structural geologist in the world today. 
Jacques Angelier had great enthusiasm and an extraordinary capacity for hard work, both in the office and in the field. He showed great ability to think and draw in three dimensions (Figs. 5 and 6). His scientific approach in the field was primarily geometric, in which his ability to visualise in three dimensions was of enormous benefit. Many of the sketches from his field notebooks (Figs. 5 and 6) were so good that they could be used essentially unmodified in his publications. He had a fine handwriting, and his field notebooks are a model of clarity and organisation.

Jacques genuinely liked fieldwork. Every year he spent many weeks in the field. Much of his fieldwork focused not on general mapping of structures or on large-scale features, but rather on accurate measurements, particularly of slickensides and fault displacements. As is well known to field geologists, mapping is a sort of detective work where, if all goes well, the picture of the structures or geological events gradually becomes clearer as the work progresses. The rewards for the work are therefore essentially instantaneous - the results become clear during the fieldwork itself. To most field geologists accurate quantitative measurements of numerous similar structures, such as slickensides or fault displacements, are tedious and far from exciting in themselves. Normally, the most important results only become clear once the data have been analysed through computer programs and models and put in general geodynamic context. To carry out a huge number of such measurements in the field every year requires great scientific enthusiasm and stamina, particularly when doing fieldwork in places such as Iceland, where the weather conditions are often poor. Jacques had abundant enthusiasm and the stamina for difficult fieldwork.

Jacques was a man of culture. He appreciated good paintings, had attended drawing classes for fine art himself, and particularly liked some of the paintings of the Spanish surrealist Salvador Dali. He had also learned to play the piano and sometimes played for us - and quite well - during the evenings after fieldwork. He was particularly fond of the piano works of the French composer Erik Satie. Jacques also read widely. Outside science, perhaps his greatest reading interests were history books.

Among Jacques Angelier's most distinctive characteristics were his very positive attitude towards people and life and his great sense of humour (Fig. 7). He loved to tell stories, and 
was very good at it. He very easily spotted the funny side of events and people and could develop these into entertaining stories and character sketches, commonly through the use of nicely worded understatements with a mild irony. Some of the stories and comments may not have been entirely 'politically correct', but none had any hint of malice, and they were genuinely entertaining and funny. He was really an excellent conversationalist and dining with Jacques was always a great pleasure.

The papers presented in 'Crustal Stresses, Fractures, and Fault Zones' reflect the scientific legacy of Jacques Angelier, both his fieldwork and his theoretical work. The topics discussed in these papers range from primarily field-based tectonic studies to primarily theoretical mechanical studies. There are papers that deal with regional geodynamic development of areas in Russia, while others focus on the seismotectonics of specific and currently active areas in Iceland, the United States, Iran, and Canada. There are also papers on plate tectonics, vertical stresses, pseudotachylyte, fluid pressure, earthquakes, mineral veins, joints, fault activity, and, of course, many papers on the fault-slip method for determining the state of stress in the Earth's crust.

This Special Issue reflects only a part of the great scientific legacy of Jacques Angelier (Fig. 8). His impact on structural geology, in particular on the study of brittle deformation and crustal stresses, has been enormous and will continue to be so for many years to come. To his many students, colleagues, and friends, however, Jacques Angelier was not only a great geologist but also a fine human being whose memory lives on. 
Figure captions

Fig. 1. Jacques in Hong Kong in 1986.

Fig. 2. Jacques studying a joint surface near Rockville in Utah, the United States, in 1987.

Fig. 3. Jacques making GPS measurements in the rift zone of Southwest Iceland in 2006.

Fig. 4. Jacques writing in his notebook in a quarry in Taiwan in 2002.

Fig. 5. Illustration and data from a notebook of Jacques showing a sketch made in 1987 of a joint surface in Utah, the United States.

Fig. 6. Illustration from a notebook of Jacques showing a sketch made in 1987 of a large fault plane on the eastern coast of the Skagi Peninsula in North Iceland.

Fig. 7. Jacques sitting in the barrel (standing: Thierry Villemin) during fieldwork in North Iceland in 1991.

Fig. 8. Jacques studying a recent fault plane in Taiwan in 1997. 


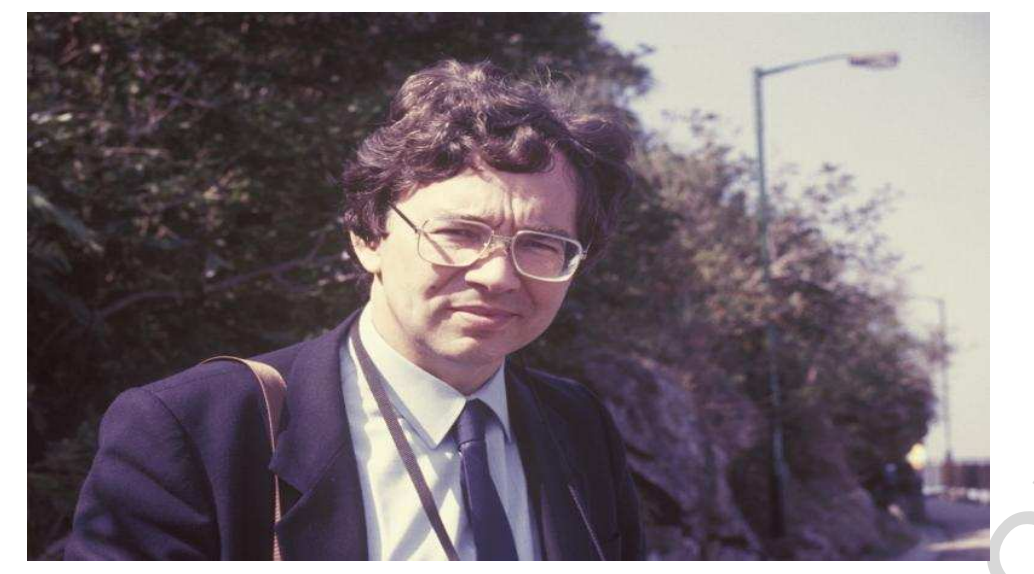

Figure 1

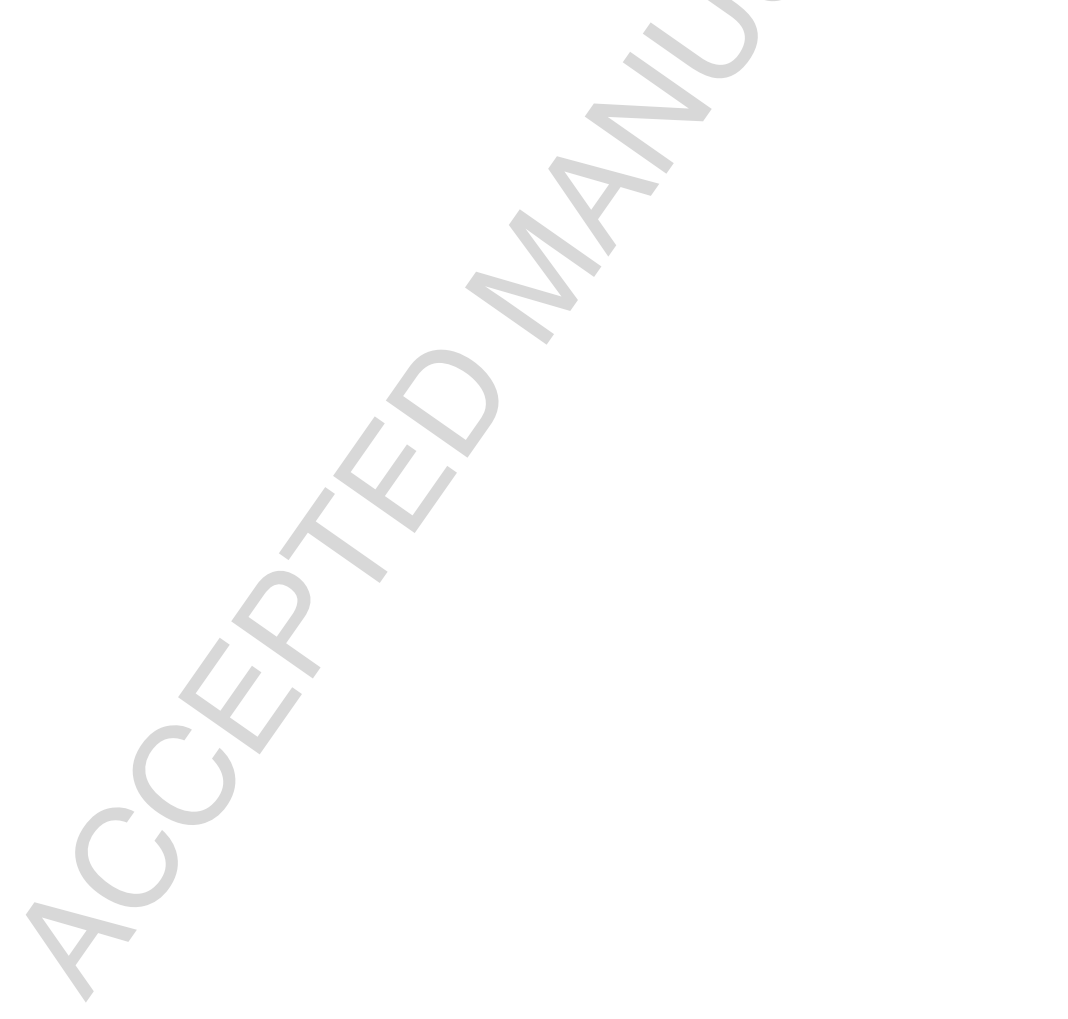



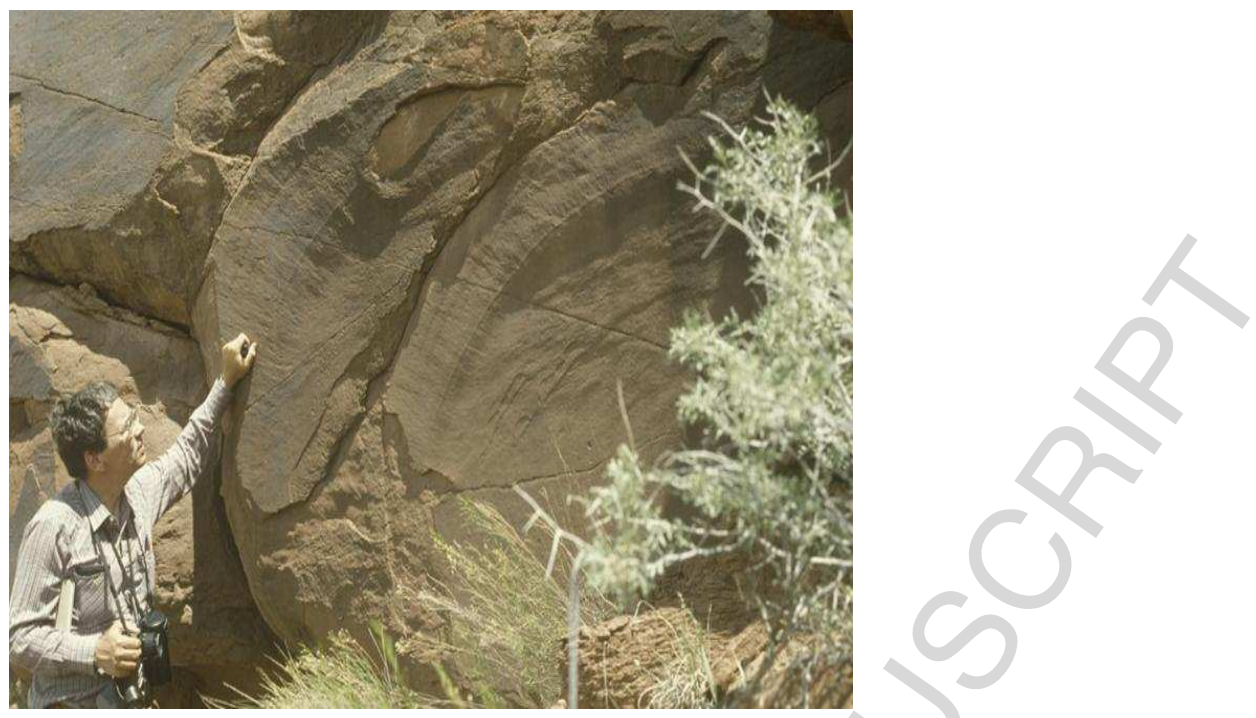

Figure 2

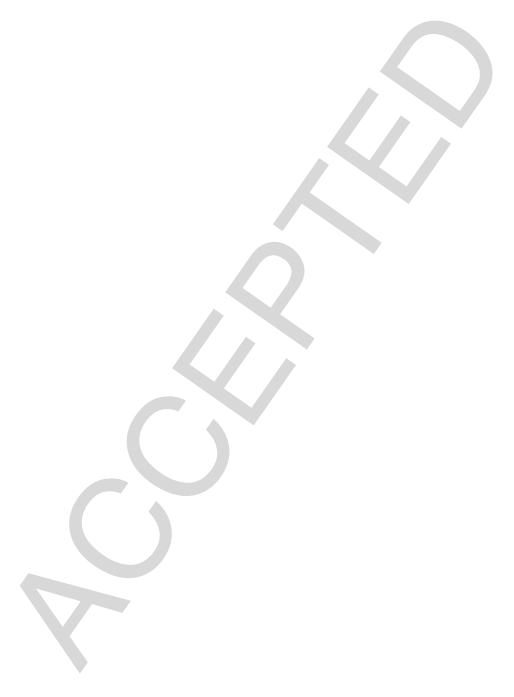




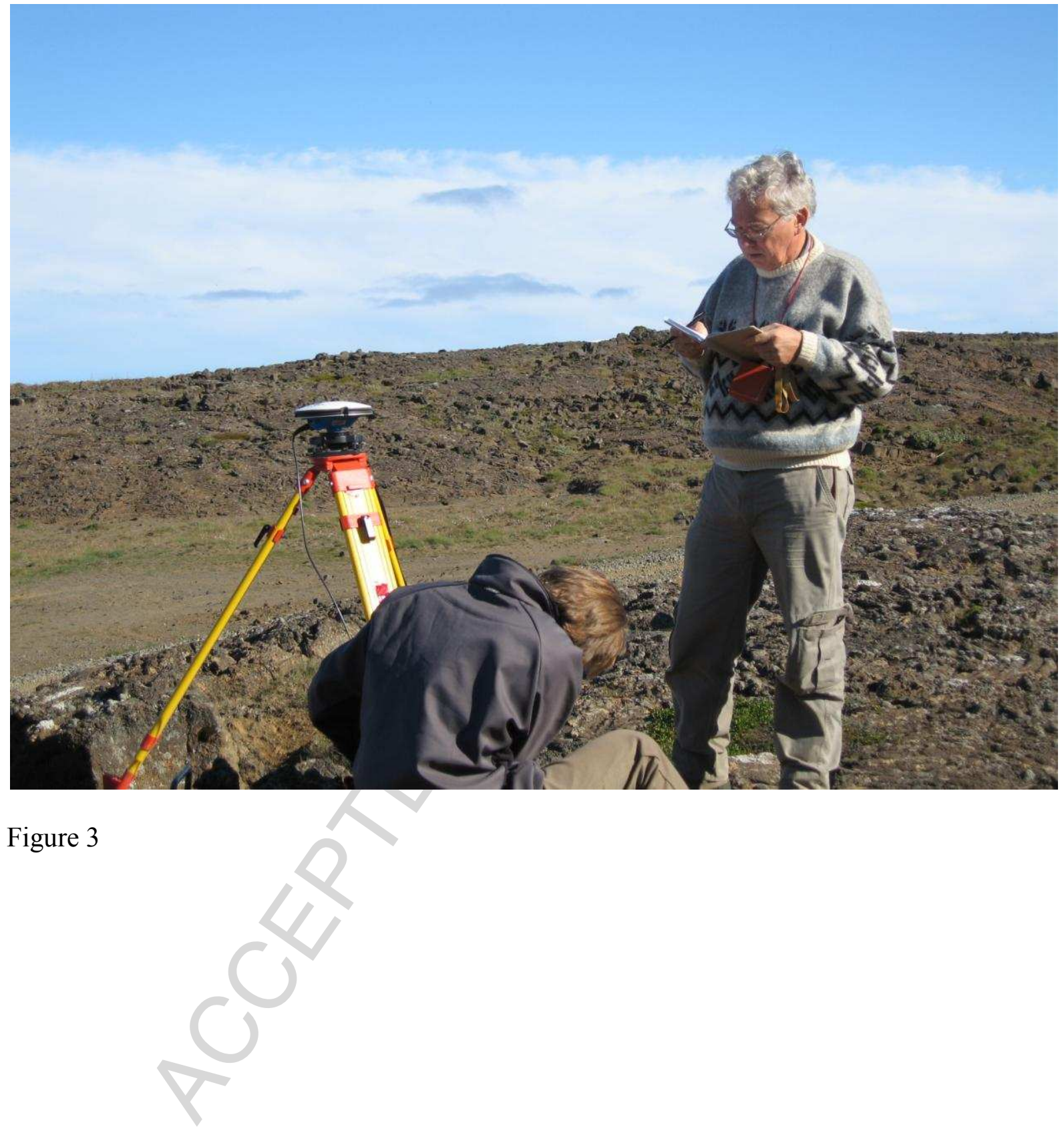




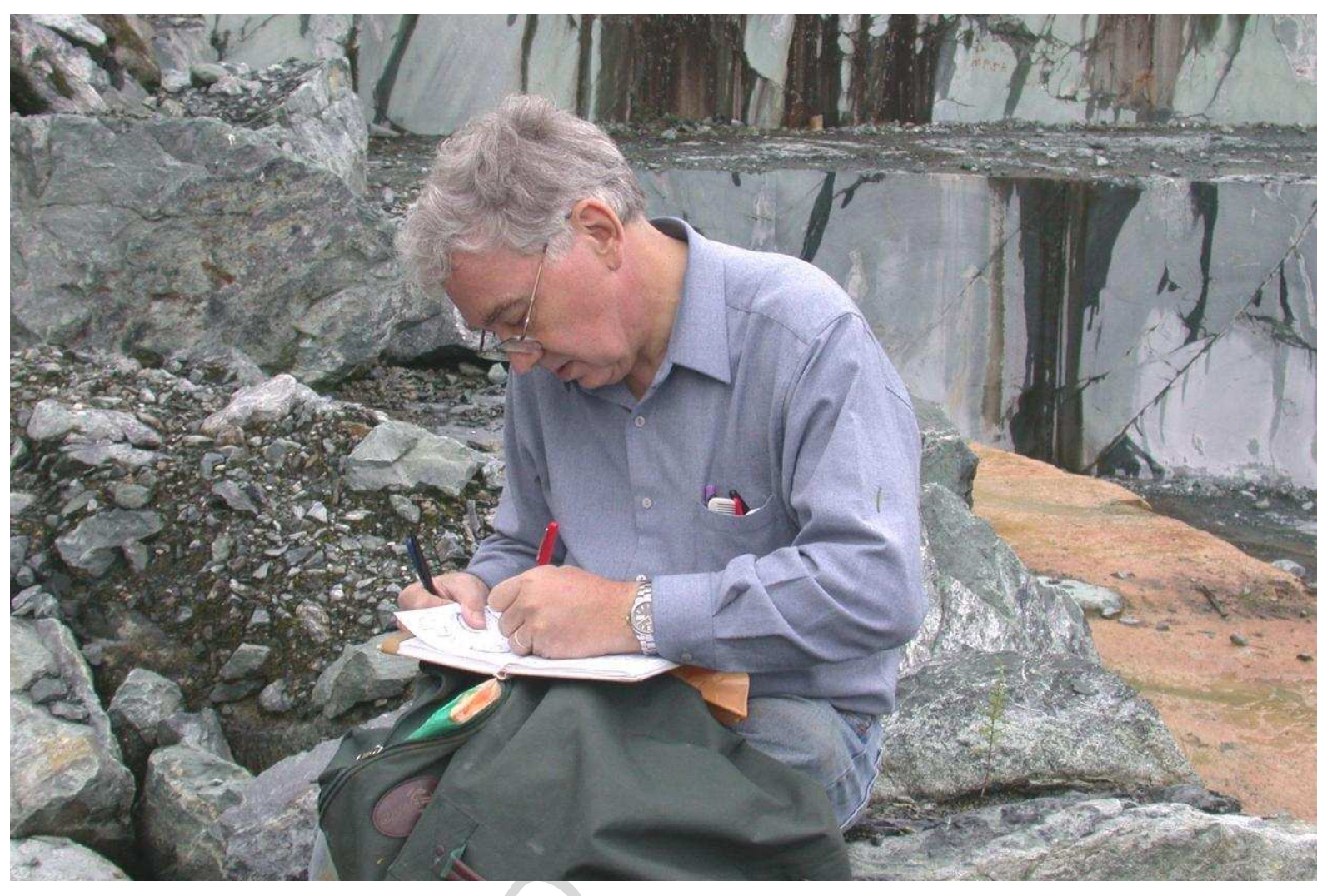

Figure 4

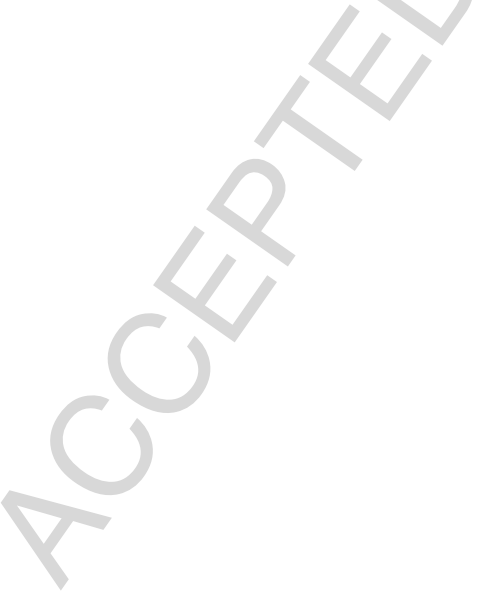




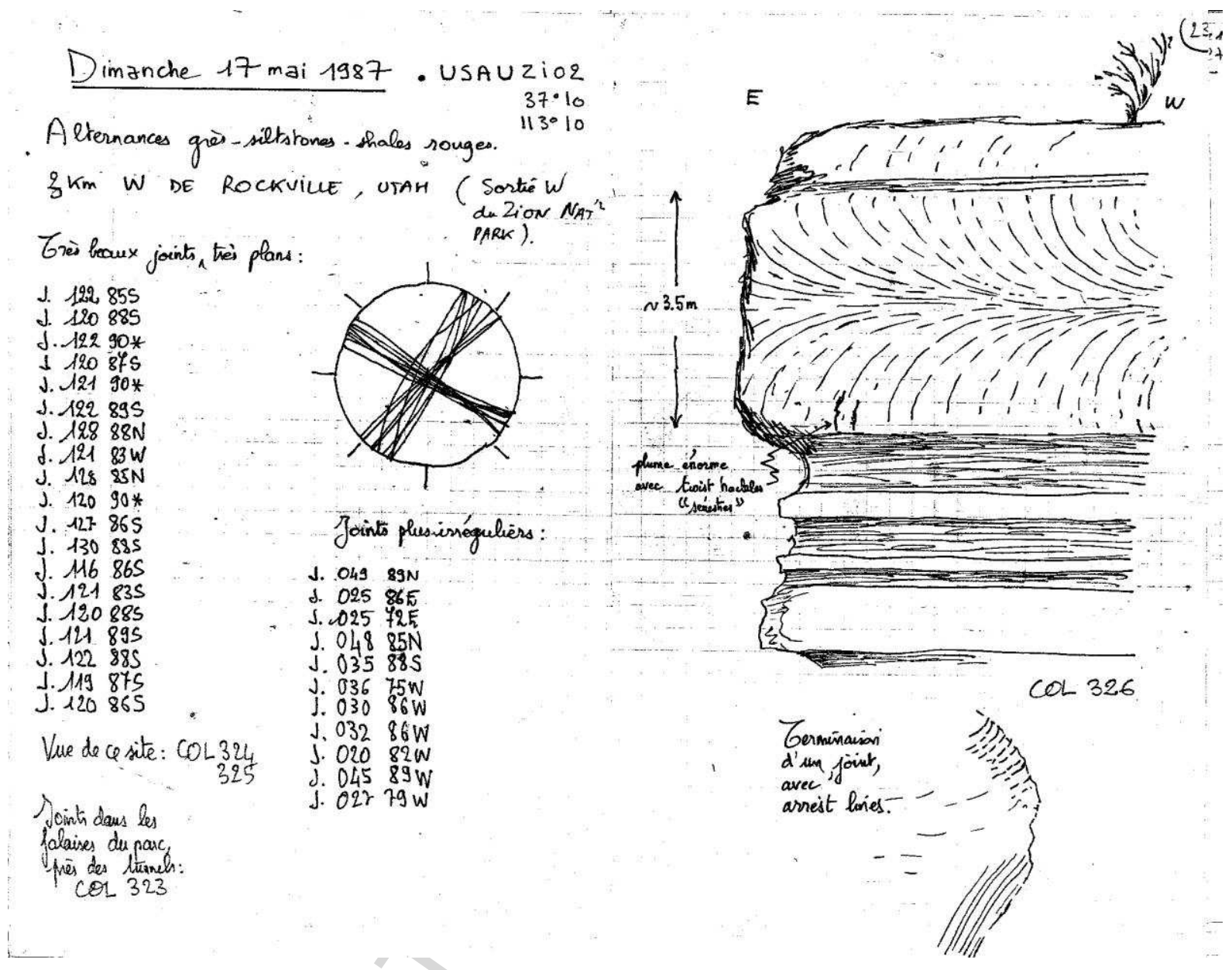

Figure 5 


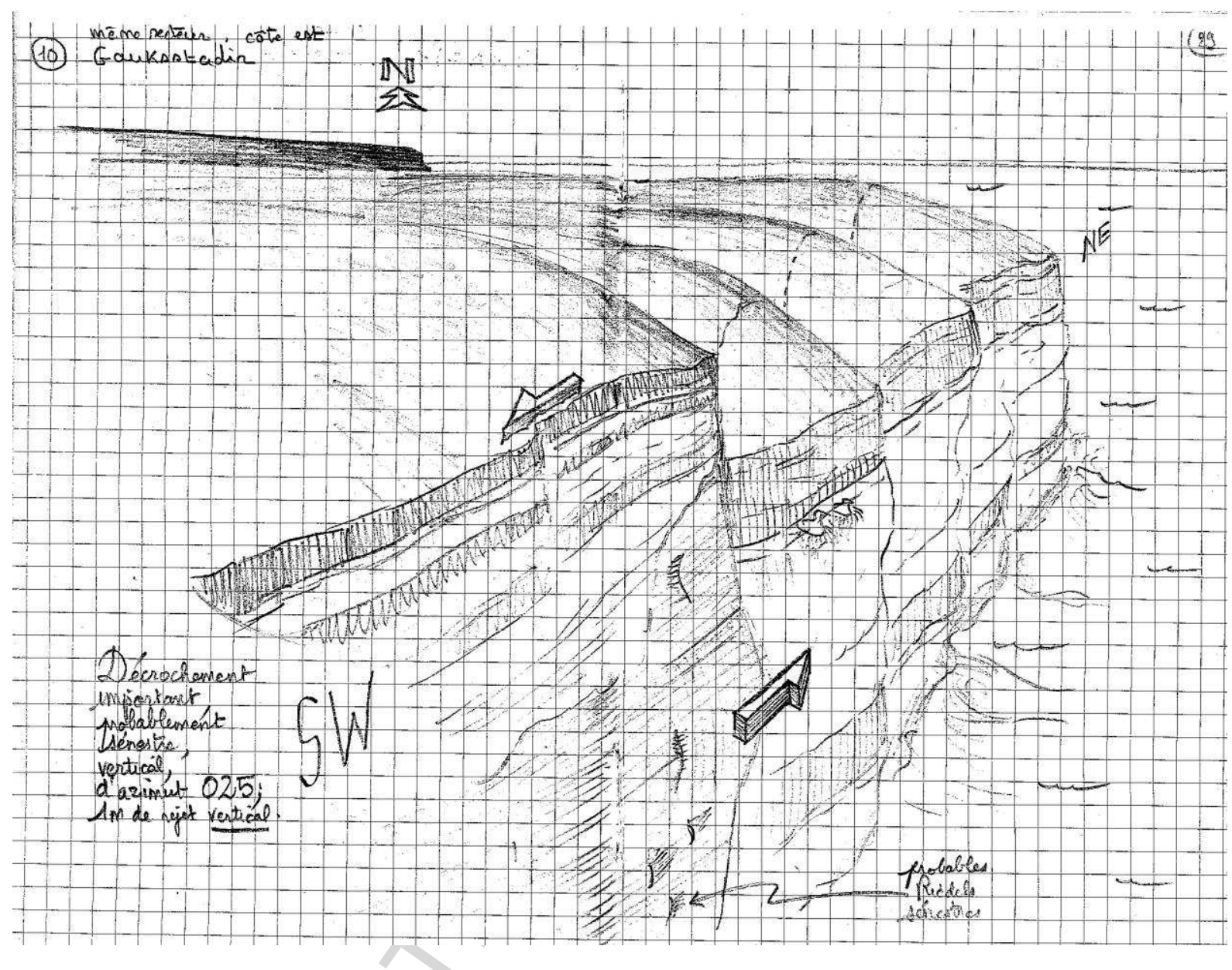

Figure 6 


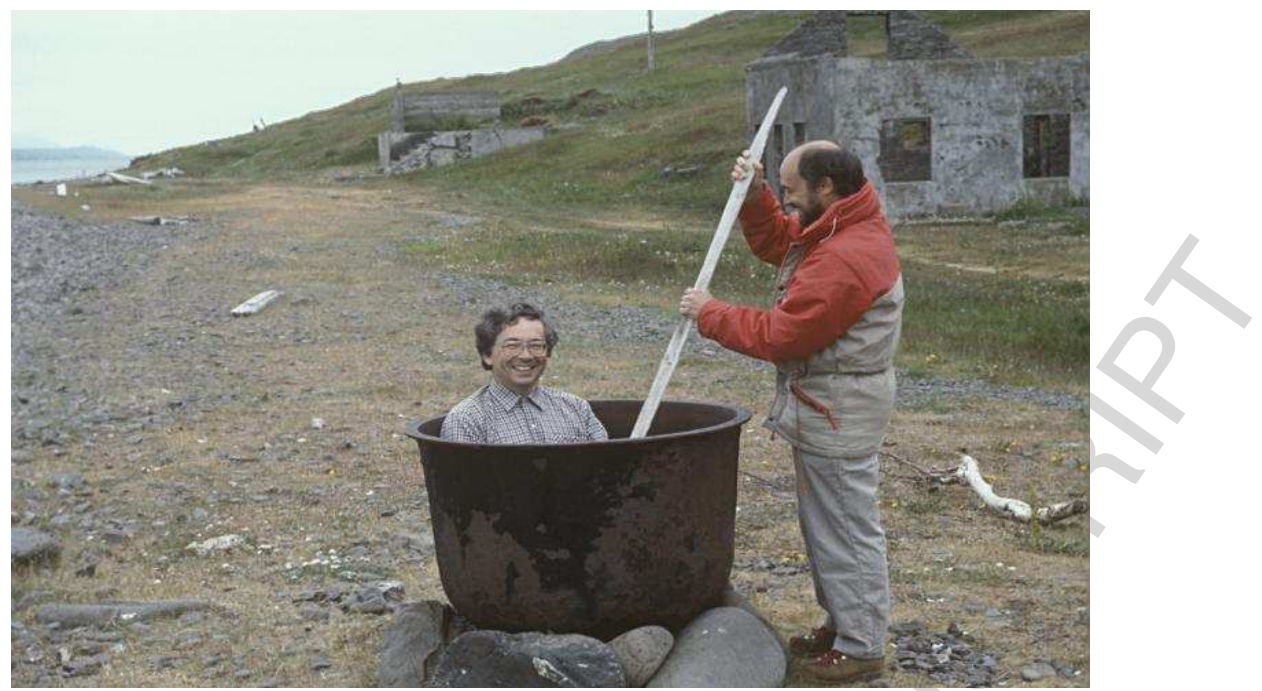

Figure 7

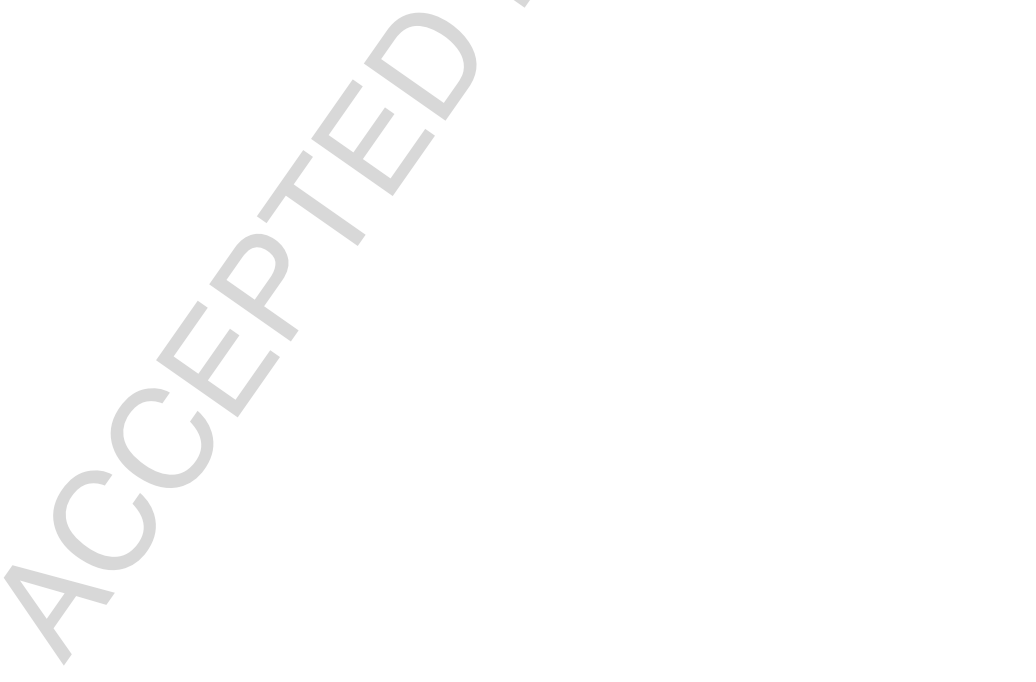




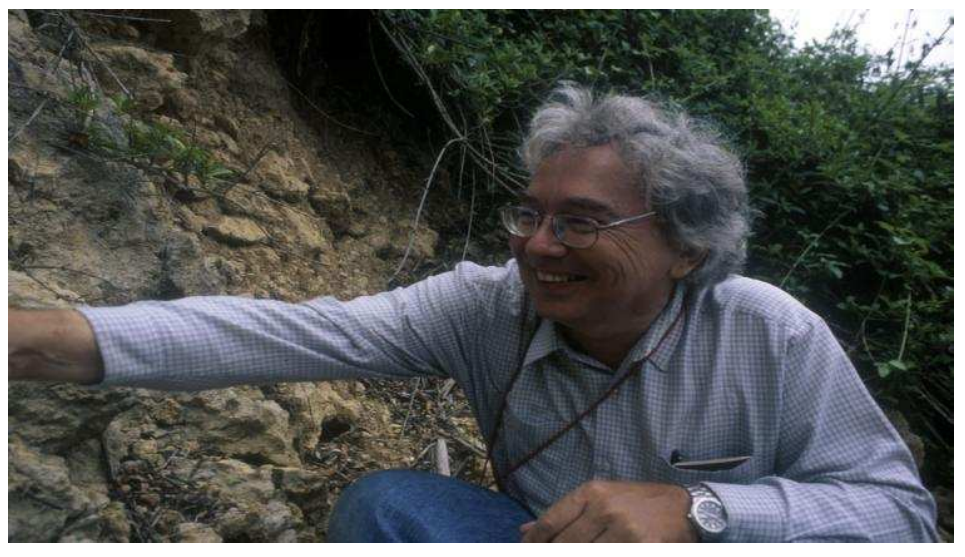

Figure 8 